\title{
ARAŞTIRMA/RESEARCH
}

\section{Clinical features of chronic hepatitis B patients}

\author{
Kronik hepatit B hastalarının klinik özellikleri
}

Ferit Kuşcu ${ }^{1}$, Aslihan Ulu ${ }^{1}$, Süheyla Kömür${ }^{1}$, Filiz Kibar², Ayşe Seza İnal ${ }^{1}$, Behice Kurtaran ${ }^{1}$, Yeşim Taşova ${ }^{1}$, Akgün Yaman², Hasan Salih Zeki Aksu ${ }^{1}$

${ }^{1}$ Cukurova University Faculty of Medicine, Department of Infectious Diseases and Clinical Microbiology, ${ }^{2}$ Department of Clinical Microbiology, Adana, Turkey

\begin{abstract}
Purpose: We aimed to evaluate the clinical features and genotypic distribution of chronic HBV patients.

Materials and Methods: The patients with chronic HBV infection were evaluated retrospectively. Biochemical tests, HBV DNA, viral genotyping in the serum samples and liver biopsy results of the patients were evaluated. The properties of the patients who were divided into two groups as Hbe ag positive and Hbe ag negative were compared.

Results: HBV genotype D was found in all of the 58 patients $(100 \%)$ included in the study. The mean age of the patients was found to be $40(18-71)$ years. $34(58.6 \%)$ of the patients were male and $24(41.4 \%)$ were female. The number of Hbe ag positive patients was found to be 13 $(22 \%)$ and the number of Hbe ag negative patients was found to be $45(78 \%)$.

Conclusion: HBV genotype is a parameter that may affect the mode of transmission and prognosis of the disease and the rates of treatment response. Thus, information related with the HBV genotypes in a region or country is a significant epidemiological finding because it will provide significant predictions related with the dynamics of dissemination of the virus and the rates of treatment response.
\end{abstract}

Key words: Hepatitis B, genotype, seroconversion

\section{INTRODUCTION}

Hepatitis B virus (HBV) is a partially doublestranded DNA virus and may lead to different clinical presentations such as acute, fulminant or chronic hepatitis ${ }^{1}$. HBV is one of the leading causes of chronic viral infections and it has been estimated that there are more than 350 million chronic carriers

\section{Öz}

Amaç: Kronik hepatit B tanılı hastaların klinik özellikleri ve genotipik dağılımlarının değerlendirilmesi amaçlanmıştır.

Gereç ve Yöntem: Kronik hepatit B tanısı ile Ocak 2011 ve Ocak 2012 tarihleri arasinda Enfeksiyon Hastalıkları polikliniğine başvuran hastalar retrospektif olarak değerlendirilmiştir. Hastaların serum örneklerinde bakılan biyokimyasal testler, HBV DNA ve viral genotipleme testleri ve ayrıca karaciğer biyopsisi ile histopatolojik evreleme sonuçları gözden geçirildi. Hbe ag pozitif ve negatif olmak üzere iki gruba ayrılan hastaların özellikleri karşılaştırıldı.

Bulgular: Calıșmaya dahil edilen 58 hastanın hepsinde $(100 \%)$ HBV genotip D tespit edildi. Hastaların yaş ortalamas1 40 (18-71) idi. Hastaların 34' ü (58.6\%) erkek, 24 'ü $(41.4 \%)$ ise kadındı. Hbe ag pozitif hasta sayısı 13 $(22 \%)$, Hbe ag negatif hasta sayıs1 ise $45(78 \%)$ idi.

Sonuç: HBV genotipleri, hastalığın bulaş yolunu, seyrini ve verilen tedaviye yanıt oranlarını etkileyebilecek bir parametredir. Dolayısıyla bir bölgedeki veya ülkedeki HBV genotiplerinin bilinmesi, virusun yayılım dinamiği ve uygulanacak tedavilere yanıt oranlarının nasıl olacağı hakkında önemli öngörüler sağlayacağı için önemli bir epidemiyolojik bulgudur.

Anahtar kelimeler: Hepatit B, genotip, serokonversiyon

in the world despite the effective prophylactic vaccines $^{2}$. Chronic carriers may develop complications including liver cirrhosis and hepatocellular carcinoma ${ }^{3}$.

$\mathrm{HBV}$ is differentiated into several genotypes labeled A to $\mathrm{J}$. Genotype A is detected in northwestern Europe, North America and Africa; Genotype B and $\mathrm{C}$ are found in Asia and Ocenia; Genotype D is 
more common in the Mediterranean countries, the Middle East, and India; Genotype $\mathrm{E}$ is found in West Coast of Africa. Genotypic diversity of the HBV can affect the disease progression and response to interferon based therapy ${ }^{3-5}$.

In this study we aimed to evaluate the clinical features and genotypic distribution in chronic HBV patients in southern Turkey.

\section{MATERIALS AND METHODS}

\section{Patients}

The patients admitted to the Infectious Diseases outpatient clinic with chronic HBV infection between October 2010 and May 2011 were evaluated retrospectively. The patients who had Hbs ag positivity for longer than 6 months were considered to have chronic HBV infection. Antiviral treatment was started in patients with chronic hepatitis B in accordance with the Turkish public health system.

Hbs Ag, Hbe Ag and Anti Hbe states were specified by "Microparticle Enzyme Immunassay" (Abbott ARCHITECT i2000). Serum alanine aminotransferase (ALT) and aspartate transaminase (AST) values were measured by routine automated systems and a value of $40 \mathrm{IU} / \mathrm{L}$ was considered the upper limit. The liver biopsy samples obtained from the patients were evaluated by the pathology division of our hospital with Knodell classification according to histological activity indexes and fibrosis stages.

\section{HBV DNA extraction, quantification and genotyping}

HBV DNA detection and quantification was made using The COBAS ${ }^{\circledR}$ ampliPrep/COBAS ${ }^{\circledR}$ TaqMan ${ }^{\circledR}$ HBV Test, version 2.0 Real Time PCR assay (Roche Molecular Systems). Genotyping of Hepatitis B virus was performed by using the INNO-LiPA HBV genotyping kit (Innogenetics, Belgium), according to the manufacturer's instructions. The test is a line probe assay designed to identify HBV genotypes (A,B,C,D,E,F,G,H) by the detection of type-specific sequences in the HBV polymerase gene domain $\mathrm{B}$ to $\mathrm{C}$. This is a reverse hybridization method. In the first step, HBV DNA was extracted using Total Nucleic Acid Isolation Kit on the MagNA Pure LC 2.0 instrument (Roche Diagnostics $\mathrm{GmbH}$, Roche Applied Science,
Mannheim, Germany). The purified DNA was amplified over two rounds of PCR by using biotinylated PCR primers. A part (domain B and C) of the HBV polymerase gene was amplified (first round). A nested PCR (second round) was performed by amplified product of the first round PCR. After amplification, biotinylated DNA material generated from the $\mathrm{HBs} \mathrm{Ag}$ open reading frame was hybridized with specific oligonucleotide probes immobilized as parallel lines on membranebased strips. Unhybridized DNA was washed from the strip and then, streptavidin labeled with alkaline phosphatase was added and bound to biotinylated hybrid. Addition of BCIP/NBT cromogenic substrate (5-bromo-4-chloro-3-indolylphosphate/4nitro-blue tetrazolium in dimethylformamide) resulted in a purple/brown precipitate line. A line is considered positive when a clear purple/brown band appears at the end of the test procedure. The INNO-LiPA HBV Genotyping strip contains one red marker line, 2 control lines and 14 parallel probe lines. The conjugate control line is a control for the color development reaction and the amplification control line contains universal HBV probes to check the presence of amplified HBV genomic material. HBV genotypes were determined using the kit interpretation chart.

\section{Statistical Analysis}

Statistical analysis was performed using the SPSS v20.0 package program. In descriptive statistics, the continuous variables were expressed as mean and standard deviation and the discrete variables were expressed as median and range. Comparison between categorical variables was performed using Fisher's exact test and comparison between continuous variables was performed using t-test or Mann-Whitney $U$ test. A p value of $<0,05$ was considered statistically significant.

\section{RESULTS}

The mean age of 58 patients included in the study was $40(18-71)$ years. $34(58.6 \%)$ of the patients were male and $24(41.4 \%)$ were female. The mean AST and ALT values were found to be 39.4 \pm 28.6 $\mathrm{U} / \mathrm{L}$ and $63.8 \pm 62.0 \mathrm{U} / \mathrm{L}$. The median value of $\mathrm{HBV}$ DNA $\log 10$ was found to be 5.12 (2.40-8.23). Liver biopsy was performed in 54 of the patients and the median Knodell score and Fibrosis values were found to be $6(2-16)$ and 2 (0-6), respectively. 
A diagnosis of hepatic cirrhosis was made histopathologically in only one of the patients. The number of Hbe ag positive patients was found to be $13(22 \%)$ and the number of Hbe ag negative patients was found to be $45(78 \%)$. When the patients were divided into two groups as Hbe ag positive and negative patients, no statistically significant difference was found between the groups in terms of gender and Fibrosis and Knodell scores. The mean age was statistically significantly lower and AST, ALT and HBV DNA levels were higher in Hbe Ag positive patients (Table 1). The inital drugs used in 37 patients who met treatment initiation criteria and secondary drugs given to 10 of these patients in whom drug treatment was changed because of unresponsiveness are shown in Table 2 .
Drug treatment was changed in one of the Hbe Ag positive patients and in 9 of the Hbe Ag negative patients. No statistically significant difference was found between the groups in terms of drug treatment change. Drug treatment was changed in all three patients $(100 \%)$ in whom pegylated interferon was initiated, in $6(67 \%)$ of 9 patients in whom lamivudine was initiated and in $1(100 \%)$ patient in whom adefovir was initiated. The patients in whom telbivudin, entecavir and tenofovir were initiated did not need any change in drug treatment.

HBs ag loss did not occur in any patient and Anti Hbe seroconversion did not develop in any of the Hbe ag positive patients. Genotype D was found in all samples obtained from 58 patients.

Table 1.Characteristics of the Hbe ag positive and negative patients

\begin{tabular}{|l|c|c|c|}
\hline \multicolumn{1}{|c|}{ Characteristic } & Hbe Ag positive (n=13) & $\begin{array}{c}\text { Hbe Ag negative } \\
\mathbf{( n = 4 5 )}\end{array}$ & p value \\
\hline Age (mean \pm SD) & $27 \pm 8$ & $43 \pm 12$ & 0.0001 \\
\hline Gender (Male/Female) & $10 / 3$ & $24 / 21$ & 0.128 \\
\hline ALT, U/L(mean \pm SD) & $90.2 \pm 77.3$ & $56.2 \pm 55.5$ & 0.006 \\
\hline AST, U/L (mean \pm SD) & $51.4 \pm 41.0$ & $35.9 \pm 23.4$ & 0.031 \\
\hline $\begin{array}{l}\text { HBV DNA log10, IU/mL } \\
\text { (median, range) }\end{array}$ & $8,23(6.82-8.23)$ & $4.57(2.40-8.23)$ & 0.0001 \\
\hline $\begin{array}{l}\text { Knodell Score (median, } \\
\text { range) }\end{array}$ & $7(4-12)$ & $6(2-16)$ & 0.479 \\
\hline Fibrosis (median, range) & $2(1-3)$ & $2(0-6)$ & 0.846 \\
\hline $\begin{array}{l}\text { Number of patients who } \\
\text { needed change in drug } \\
\text { treatment }(\%)\end{array}$ & $1(8 \%)$ & $9(20 \%)$ & 0.08 \\
\hline
\end{tabular}

Table 2. Initial antiviral treatments and switched second-line drugs due to unresponsiveness.

\begin{tabular}{|l|l|}
\hline Initial Therapy $(\mathrm{n}=3 \mathbf{3})$ & Switched Therapy $(\mathrm{n}=\mathbf{1 0})$ \\
\hline Pegylated interferon $\alpha-2 \mathrm{a}(\mathrm{n}=3)$ & Lamivudin $(\mathrm{n}=1)$ \\
& Telbivudin $(\mathrm{n}=1)$ \\
& Tenofovir $(\mathrm{n}=1)$ \\
\hline Lamivudin $(\mathrm{n}=9)$ & Tenofovir $(\mathrm{n}=5)$ \\
& Entekavir $(\mathrm{n}=1)$ \\
\hline Adefovir $(\mathrm{n}=1)$ & Tenofovir $(\mathrm{n}=1)$ \\
\hline Telbivudin $(\mathrm{n}=5)$ & - \\
\hline Entecavir $(\mathrm{n}=7)$ & - \\
\hline Tenofovir $(\mathrm{n}=12)$ & - \\
\hline
\end{tabular}

\section{DISCUSSION}

Individuals with chronic $\mathrm{HBV}$ infection go through different phases including immunotolerant, immunoclearance, inactive, reactivation and immune control phases. Many factors including viral replication and mutations, the immune response level of the host, age, gender, ethnic origin, comorbidity, socioeconomical level and HBV genotype determine the natural course of $\mathrm{HBV}$ infection ${ }^{7,8}$.

In a portion of patients with chronic HBV infections who develop $\mathrm{HbeAg}$ seroconversion, normal serum ALT levels, HbeAg loss and anti 
HbeAb development and undetectable HBV DNA levels (inactive phase) are achieved. In some patients, HBV replication continues despite a negative Hbe $\mathrm{Ag}$ and increased ALT levels and moderate or advanced changes in hepatic histology are found (reactivation phase) as a result of mutations developing in the precore or basal core promoter regions of the virus, 8 . Precore and basal core promoter mutations are frequently observed in HBV genotype D variants and cause to Hbe ag negative chronic $\mathrm{HBV}$ infection ${ }^{8}$. In our study, the reason that the rate of $\mathrm{Hbe} \mathrm{Ag}$ negative patients was found to be high $(78 \%)$ was the fact that all our patients were infected with HBV genotype D. In different studies conducted in our country, it was reported that the predominant genotype is genotype D. In the study conducted by Atalay et al., genotype $\mathrm{D}$ was found in 107 (97.2\%) of 110 patients and genotyping was not performed in 3 patients; the rate of Hbe ag negative patients was found to be $82 \%$ similar to our study ${ }^{10}$. In another multi-center study in which the genotype distribution of acute hepatitis $\mathrm{B}$ patients was investigated, genotype $\mathrm{D}$ was found in 147 of 158 patients and typing could not be made in 11 patients ${ }^{11}$. Similarly, the predominant genotype was shown to be genotype $\mathrm{D}$ in all studies conducted in different regions of Turkey ${ }^{12-14}$.

The final objective in treatment of hepatitis B is Hbs ag seroconversion, but this outcome is obtained with a rate of $3 \%$ with interferon or pegylated interferon and with a rate of $1 \%$ with oral antivirals administered for one year ${ }^{15}$. Hbs ag seroconversion was not observed in any of our patients. In different studies, no difference could be found in the rates of response to nucleotide analogues between $\mathrm{HBV}$ genotypes, whereas HBV genotype D infections had a lower rate of response to interferon treatment ${ }^{16,17}$. Although the number of patients was low, oral antivirals had to be initiated because of unresponsiveness to pegylated interferon treatment in three of our patients.

It is possible to provide a strong and long-term viral suppression by preventing viral replication with nucleoside analogues used in treatment of chronic HBV treatment. However, the disadvantages of these antiviral drugs include failure to reach satisfactory rates in Hbs ag eradication, requirement for using these drugs for a lifetime and potential of development of resistance ${ }^{18}$. Lamivudine is the first nucleoside analogue approved for HBV treatment. It is used widely because it is pharmacoeconomically advantageous compared to the other molecules. In chronic HBV patients treated with lamivudine, resistance is observed with a rate of about $20 \%$ at the end of one year and with a rate of about $70 \%$ at the end of five years ${ }^{19}$. In our study, change in drug treatment was needed with a very high rate $(67 \%)$ in the patients in whom lamivudine treatment was initiated because of an increase in viral load. An efficient viral suppression was provided in the patients in whom treatment with tenofovir and entecavir was initiated and their treatments are being continued. Lamivudine is not one of the first-line drug in treatment of HBV infection because of high resistance rates. Potent antivirals including entecavir and tenofovir should be the first-line drugs ${ }^{20}$.

A limitation of our study was the fact that different HBV genotypes could not be compared in terms of treatment response or disease progression, because HBV genotype D was found in all patients included in the study. In addition, it is thought that there may be clinical and/or viral differences between the subgenotypes of HBV genotype D as a result of the studies conducted ${ }^{21}$. We could not evaluate our patients in this regard, because we did not have HBV subgenotype results.

Studies have shown that the structural and functional differences between HBV genotypes may affect the mode of transmission, prognosis, severity and progression of the disease, potential complications and the rates of treatment response in $\mathrm{HBV}$ infection ${ }^{22}$. Hence, information related with the HBV genotypes in our country is a significant epidemiological finding, because it will provide significant predictions related with the dynamics of dissemination of the virus and the rates of treatment response ${ }^{23}$. Although the predominant genotype was found to be genotype $\mathrm{D}$ in all different studies conducted in Turkey, our specific region harbors a potential of change in HBV genotypes in time, because it harbors both refugees of war and intensive human traffic. Therefore, the distribution of HBV genotype should be investigated with certain intervals because it will provide significant ideas related with the dynamics of the disease.

\section{REFERENCES}

1. Seeger C, Mason WS. Hepatitis B virus biology. Microbiol Mol Biol Rev. 2000;64:51-68.

2. Liaw YF, Chu CM. Hepatitis B virus infection. Lancet. 2009;373:582-92.

3. Trepo C, Chan HL, Lok A. Hepatitis B virus 
infection. Lancet. 2014;384:2053-63.

4. Sunbul M. Hepatitis B virus genotypes: global distribution and clinical importance. World J Gastroenterol 2014;20:5427-34.

5. Lindh M, Andersson AS, Gusdal A. Genotypes, nt 1858 variants, and geographic origin of hepatitis B virus-largescale analysis using a new genotyping method. J Infect Dis. 1997;175:1285-1293.

6. Lok AS, McMahon BJ. AASLD Practice Guideline Update. Chronic Hepatitis B: Update 2009. Hepatology. 2009;50:661-662.

7. Fattovich G, Bortolotti F, Donato F. Natural history of chronic hepatitis B:special emphasis on disease progression and prognostic factors. J Hepatol. 2008;48:335-52.

8. Kim BK, Revill PA, Ahn SH. HBV genotypes: relevance to natural history, pathogenesis and treatment of chronic hepatitis B. Antivir Ther. 2011;16:1169-86.

9. McMahon BJ. Epidemiology and natural history of hepatitis B. Semin Liver Dis. 2005;25:3-8.

10. Atalay MA, Gokahmetoglu S, Aygen B. Genotypes of hepatitis B virus in Central Anatolia, Kayseri, Turkey. Saudi Med J. 2011;32:3630-33.

11. Leblebicioglu H, Eroglu C. Acute hepatitis B virus infection in Turkey: epidemiology and genotype distribution. Clin Microbiol Infect. 2004;10:537-41.

12. Ciftci S, Keskin F, Badur S: Clinical features of hepatitis B virus genotypes in Turkish patients. J Pak Med Assoc. 2012;62:759-63.

13. Emekdaş G, Tezcan S, Aslan G, Serin MS, Sezgin O, Uçbilek E et al.. Determination of hepatitis B virus genotypes in chronic hepatitis B patients in Mersin province, Turkey. Mikrobiyol Bul. 2012;46:432-45.

14. Kaya S, Cetin ES, Aridogan BC, Onal S, Demirci M. Distribution of hepatitis B virus (HBV) genotypes among HBV carriers in Isparta. Iran Biomed J. 2007;11:59-63.

15. Moucari R, Korevaar A, Lada O, Martinot-Peignoux $\mathrm{M}$, Boyer $\mathrm{N}$, Mackiewicz $\mathrm{V}$ et al. High rates of $\mathrm{HBsAg}$ seroconversion in $\mathrm{HBeAg}$-positive chronic hepatitis B patients responding to interferon: a longterm follow-up study. J Hepatol. 2009;50:1084-92.

16. Wiegand J, Hasenclever D, Tillmann HL. Should treatment of hepatitis B depend on hepatitis B virus genotypes? A hypothesis generated from an explorative analysis of published evidence. Antiviral Ther. 2008;13:211-20.

17. Flink HJ, van Zonneveld M, Hansen BE, de Man RA, Schalm SW, Janssen HL, HBV 99-01 study group: Treatment with Peg-interferon alpha-2b for HBeAg-positive chronic hepatitis B: HBsAg loss is associated with HBV genotype. Am J Gastroenterol. 2006;101:297-303.

18. Zoulim F. Are novel combination therapies needed for chronic hepatitis B? Antiviral Res. 2012;96:256-9.

19. Lok AS, Lai CL, Leung N, Yao GB, Cui ZY, Schiff ER et al. Long-term safety of lamivudine treatment in patients with chronic hepatitis B. Gastroenterology. 2003;125:1714-22.

20. European Association For The Study Of The Liver. EASL clinical practice guidelines: Management of chronic hepatitis B virus infection. J Hepatol. 2012;57:167-85.

21. Ozaras R, Balkan II, Yemisen M, Tabak F. Epidemiology of HBV subgenotypes D. Clin Res Hepatol Gastroenterol. 2015;39:28-37.

22. Kramvis A, Kew M, François G. Hepatitis B virus genotypes. Vaccine. 2005;23:2409-23.

23. Allain JP. Epidemiology of Hepatitis B Virus and Genotype. J Clin Virol. 2006;36:12-7. 